\title{
Paracoccus rhizosphaerae sp. nov., isolated from the rhizosphere of the plant Crossostephium chinense (L.) Makino (Seremban)
}

\author{
Correspondence \\ Peter Kämpfer \\ peter.kaempfer@umwelt.uni- \\ giessen.de
}

\author{
P. Kämpfer, ${ }^{1}$ Wei-An Lai, ${ }^{2}$ A. B. Arun, ${ }^{3}$ Chiu-Chung Young, ${ }^{2}$ P. D. Rekha, ${ }^{3}$ \\ K. Martin, ${ }^{4}$ H.-J. Busse ${ }^{5}$ and Wen-Ming Chen ${ }^{6}$ \\ ${ }^{1}$ Institut für Angewandte Mikrobiologie, Justus-Liebig-Universität Giessen, D-35392 Giessen, \\ Germany \\ ${ }^{2}$ College of Agriculture and Natural Resources, Department of Soil \& Environmental Sciences, \\ National Chung Hsing University, Taichung, Taiwan, ROC \\ ${ }^{3}$ Yenepoya Research Centre, Yenepoya University, University Road, Deralakatee, Mangalore, \\ Karnataka, India \\ ${ }^{4}$ Leibniz-Institut für Naturstoff-Forschung und Infektionsbiologie eV, Hans-Knöll-Institut, \\ D-07745 Jena, Germany \\ ${ }^{5}$ Institut für Bakteriologie, Mykologie und Hygiene, Veterinärmedizinische Universität, A-1210 Wien, \\ Austria \\ ${ }^{6}$ Laboratory of Microbiology, Department of Seafood Science, National Kaohsiung Marine \\ University, Kaohsiung, Taiwan, ROC
}

A Gram-negative, coccoid-shaped bacterium, strain CC-CCM15-8 ${ }^{\top}$, was isolated from a rhizosphere soil sample of the plant Crossostephium chinense (L.) Makino (Seremban) from Budai Township, Chiayi County, Taiwan. 16S rRNA gene sequence analysis clearly allocated strain CC-CCM15-8 ${ }^{\top}$ to the Paracoccus cluster, showing highest similarities to the type strains of 'Paracoccus beibuensis' (98.8\%), Paracoccus homiensis (97.6\%), Paracoccus aestuarii (97.7\%) and Paracoccus zeaxanthinifaciens (97.7\%). The fatty acid profile, comprising $\mathrm{C}_{18: 1} \omega 7 \mathrm{c}$ as the major component and $\mathrm{C}_{10: 0} 3-\mathrm{OH}$ as the characteristic hydroxylated fatty acid, supported the placement of strain CC-CCM15-8 ${ }^{\top}$ within the genus Paracoccus. The polyamine pattern consisted of putrescine and spermidine as major components. Ubiqinone $\mathrm{Q}-10$ was the major quinone type (95\%); ubiquinone Q-9 was also detected (5\%). The complex polar lipid profile consisted of diphosphatidylglycerol, phosphatidylethanolamine, phosphatidylglycerol, phosphatidylcholine, and unidentified phospholipids, lipids and glycolipids. Levels of DNA-DNA relatedness between strain CC-CCM15-8 ${ }^{\top}$ and ' $P$. beibuensis' LMG $25871^{\top}, P$. aestuarii DSM $19484^{\top}, P$. zeaxanthinifaciens LMG $21993^{\top}$ and $P$. homiensis KACC $11518^{\top}$ were $24.9 \%$ (34.8\%, reciprocal analysis), $15.7 \%$ (17.5\%), $17.7 \%(23.4 \%)$ and $16.0 \%(25.4 \%)$, respectively. Physiological and biochemical test results allowed the phenotypic differentiation of strain CC-CCM15-8 ${ }^{\top}$ from its closest relatives in the genus Paracoccus. Based on the data presented, it is concluded that strain CC-CCM15-8 ${ }^{\top}$ represents a novel species of the genus Paracoccus, for which the name Paracoccus rhizosphaerae sp. nov. is proposed. The type strain is CC-CCM15-8 ${ }^{\top}\left(=\right.$ LMG $26205^{\top}=$ CCM $\left.7904^{\top}\right)$.
The genus Paracoccus was proposed by Davis et al. (1969), and subsequent analysis of the $16 \mathrm{~S}$ rRNA gene sequence of the type species Paracoccus denitrificans indicated that this species belongs to the $\alpha-3$ subgroup of the Proteobacteria.

The GenBank/EMBL/DDBJ accession number for the 16S rRNA gene sequence of strain CC-CCM15-8 ${ }^{\top}$ is JN662389.

A supplementary figure is available with the online version of this paper.
For species of this genus, which generally stain Gramnegative, a high metabolic versatility has been reported. They are chemotaxonomically characterized by fatty acid patterns showing a large amount of $\mathrm{C}_{18: 1} \omega 7 c$ (often $>70 \%$ of the total) and the presence of $\mathrm{C}_{10: 0} 3-\mathrm{OH}$. The major respiratory quinone is ubiquinone Q-10. Chen et al. (2011) described complex polar lipid profiles consisting of the major components diphosphatidylglycerol, 
phosphatidylglycerol, phosphatidylcholine and several uncharacterized lipids.

At the time of writing, the genus Paracoccus comprised the following recognized species: P. aestuarii (Roh et al., 2009), $P$. alcaliphilus (Urakami et al., 1989), P. alkenifer (Lipski et al., 1998), P. aminophilus and P. aminovorans (Urakami et al., 1990), P. bengalensis (Ghosh et al., 2006), P. carotinifaciens (Tsubokura et al., 1999), P. chinensis (Li et al., 2009), P. denitrificans (Beijerinck \& Minkman, 1910; Davis et al., 1969; Skerman et al., 1980 emend. Nokhal \& Schlegel, 1983; Ludwig et al., 1993), P. fistulariae (Kim et al., 2010), P. haeundaensis (Lee et al., 2004), $P$. halodenitrificans (Robinson \& Gibbons, 1952), P. halophilus (Liu et al., 2008), P. homiensis (Kim et al., 2006), P. isoporae (Chen et al., 2011), P. kocurii (Ohara et al., 1990), P. kondratievae (Doronina \& Trotsenko, 2000 emend. Doronina et al., 2002), P. koreensis (La et al., 2005), P. marcusii (Harker et al., 1998), P. marinus (Khan et al., 2008), P. methylutens (Doronina et al., 1998), P. pantotrophus (Robertson \& Kuenen, 1984; Rainey et al., 1999), P. saliphilus (Wang et al., 2009), P. seriniphilus (Pukall et al., 2003), P. solventivorans (Siller et al., 1996 emend. Lipski et al., 1998), P. sphaerophysae (Deng et al., 2011), P. sulfuroxidans (Liu et al., 2006), P. thiocyanatus (Katayama et al., 1995), P. versutus (Harrison, 1983; Katayama et al., 1995), P. yeei corrig. (Daneshvar et al., 2003), P. zeaxanthinifaciens (Berry et al., 2003); 'P. beibuensis' (Zheng et al., 2011) has recently been described but the name has not been validly published. Many of these species have been isolated from marine habitats.

Strain CC-CCM15- $8^{\mathrm{T}}$ was isolated from a rhizosphere soil sample of the plant Crossostephium chinense (L.) Makino (Seremban) from Budai Township, Chiayi County, Taiwan, on marine agar 2216 (MA; Difco) at $28{ }^{\circ} \mathrm{C}$ and was maintained further on tryptone soy agar at $28{ }^{\circ} \mathrm{C}$. The strain was preserved at $-80{ }^{\circ} \mathrm{C}$ by mixing well-grown marine broth 2216 (MB; Difco) cultures in a $1: 1$ ratio with glycerol preservation medium, containing $\mathrm{K}_{2} \mathrm{HPO}_{4}$ $(1.26 \%), \quad \mathrm{KH}_{2} \mathrm{PO}_{4} \quad(0.36 \%), \quad \mathrm{MgSO}_{4} .7 \mathrm{H}_{2} \mathrm{O}(0.01 \%)$, sodium citrate $(0.09 \%),\left(\mathrm{NH}_{4}\right)_{2} \mathrm{SO}_{4}(0.18 \%)$ and glycerol $(8.8 \%)$. Stock cultures of the isolate in marine broth supplemented with $5 \%$ DMSO were additionally maintained in the vapour phase of liquid nitrogen.

The cellular morphological features and Gram-staining behaviour were observed by phase-contrast microscopy as described previously (Kämpfer \& Kroppenstedt, 1996). The $16 \mathrm{~S}$ rRNA gene was analysed as described by Kämpfer $e t$ al. (2003).

Multiple sequence alignment and analysis of the data were performed by using the software package MEGA version 4 (Tamura et al., 2007). Genetic distance calculations (distance options according to the Kimura two-parameter model) and clustering with the neighbour-joining (Fig. 1), maximum parsimony (results not shown) and maximumlikelihood (Fig. S1 available in IJSEM Online) methods were determined by using bootstrap values based on 1000 replications. The $16 \mathrm{~S}$ rRNA gene sequence of strain CCCCM15- $8^{\mathrm{T}}$ was a continuous stretch of $1390 \mathrm{bp}$. Highest levels of 16S rRNA gene sequence similarity were found with the type strains of ' $P$. beibuensis' (98.8\%), P. homiensis (97.6\%), P. aestuarii $(97.7 \%)$ and P. zeaxanthinifaciens $(97.7 \%)$; levels of similarity with the type strains of all other Paracoccus species were lower than $97.0 \%$.

Fatty acid analysis was performed according to Kämpfer \& Kroppenstedt (1996) with cells grown on MA for $48 \mathrm{~h}$. The fatty acid profile of strain CC-CCM15- $8^{\mathrm{T}}$ was similar to those of closely related Paracoccus species, although minor quantitative differences were observed (Table 2). ' $P$. beibuensis' LMG $24871^{\mathrm{T}}$, P. aestuarii DSM $19484^{\mathrm{T}}, P$. zeaxanthinifaciens LMG $21993^{\mathrm{T}}$ and $P$. homiensis KACC $11518^{\mathrm{T}}$ were studied under the same conditions and had $\mathrm{C}_{18: 1} \omega 7 c$ as the major fatty acid together with the characteristic hydroxylated fatty acid $\mathrm{C}_{10: 0} 3-\mathrm{OH}$.

For detection of respiratory isoprenoid quinones and polar lipids, cells of strain CC-CCM15- $8^{\mathrm{T}}$ were grown in MB at $28{ }^{\circ} \mathrm{C}$ for $48 \mathrm{~h}$. Respiratory quinones were extracted according to the method of Collins et al. (1977) and were analysed by HPLC as described by Groth et al. (1996). Ubiquinones Q-10 (95\%) and Q-9 (5\%) were detected as isoprenoid quinones. Polar lipids extracted according to the method of Minnikin et al. (1979) were identified by two-dimensional TLC as described by Collins \& Jones (1980). Strain CC-CCM15-8 $8^{\mathrm{T}}$ exhibited a complex polar lipid pattern, similar to the data presented by Chen et al. (2011). In agreement with polar lipid data for $P$. isoporae SW- $3^{\mathrm{T}}$, P. aestuarii JCM $15119^{\mathrm{T}}$, P. homiensis KACC $11518^{\mathrm{T}}$, P. marinus NBRC $100637^{\mathrm{T}}$, P. denitrificans BCRC $12285^{\mathrm{T}}$ and $P$. zeaxanthinifaciens JCM $21774^{\mathrm{T}}$, strain CC-CCM15-8 ${ }^{\mathrm{T}}$ contained diphosphatidylglycerol, phosphatidylglycerol, phosphatidylcholine, an unidentified glycolipid and several unidentified polar lipids, phospholipids and glycolipids (Fig. 2). In contrast to the data presented by Chen et al. (2011), however, phosphatidylethanolamine was detected in strain CC-CCM15-8 ${ }^{\mathrm{T}}$ rather than an unidentified aminolipid. However, differences in the chromatographic motility ( $R_{\mathrm{f}}$ values) of the polar lipids could be the result of the different solvent systems used.

Biomass for polyamine analysis was grown in PYE broth ( $0.3 \%$ peptone from casein, $0.3 \%$ yeast extract, $\mathrm{pH} 7.2)$ supplemented with $3.1 \%$ sea salts (Sigma) and harvested at the late exponential growth phase $(70 \%$ of the maximum optical density). Polyamines were extracted as described by Busse \& Auling (1988) and analysed according to Stolz et al., (2007). The polyamine pattern of strain CC-CCM15$8^{\mathrm{T}}$ consisted of $23.3 \mu \mathrm{mol}$ spermidine $(\mathrm{g} \text { dry weight })^{-1}$, $10.4 \mu \mathrm{mol}$ putrescine (g dry weight $)^{-1}, 4.0 \mu \mathrm{mol}$ cadaverine $(\mathrm{g} \text { dry weight })^{-1}, 2.2 \mu \mathrm{mol} 1,3$-diaminopropane (g dry weight $)^{-1}, 0.6 \mu \mathrm{mol}$ spermine $(\mathrm{g} \text { dry weight })^{-1}$ and $0.2 \mu \mathrm{mol}$ sym-norspermidine (g dry weight $)^{-1}$. This polyamine pattern is in good agreement with data published for recognized species of the genus Paracoccus but in contrast to strain CC-CCM15- ${ }^{\mathrm{T}}$ the content of putrescine is higher 


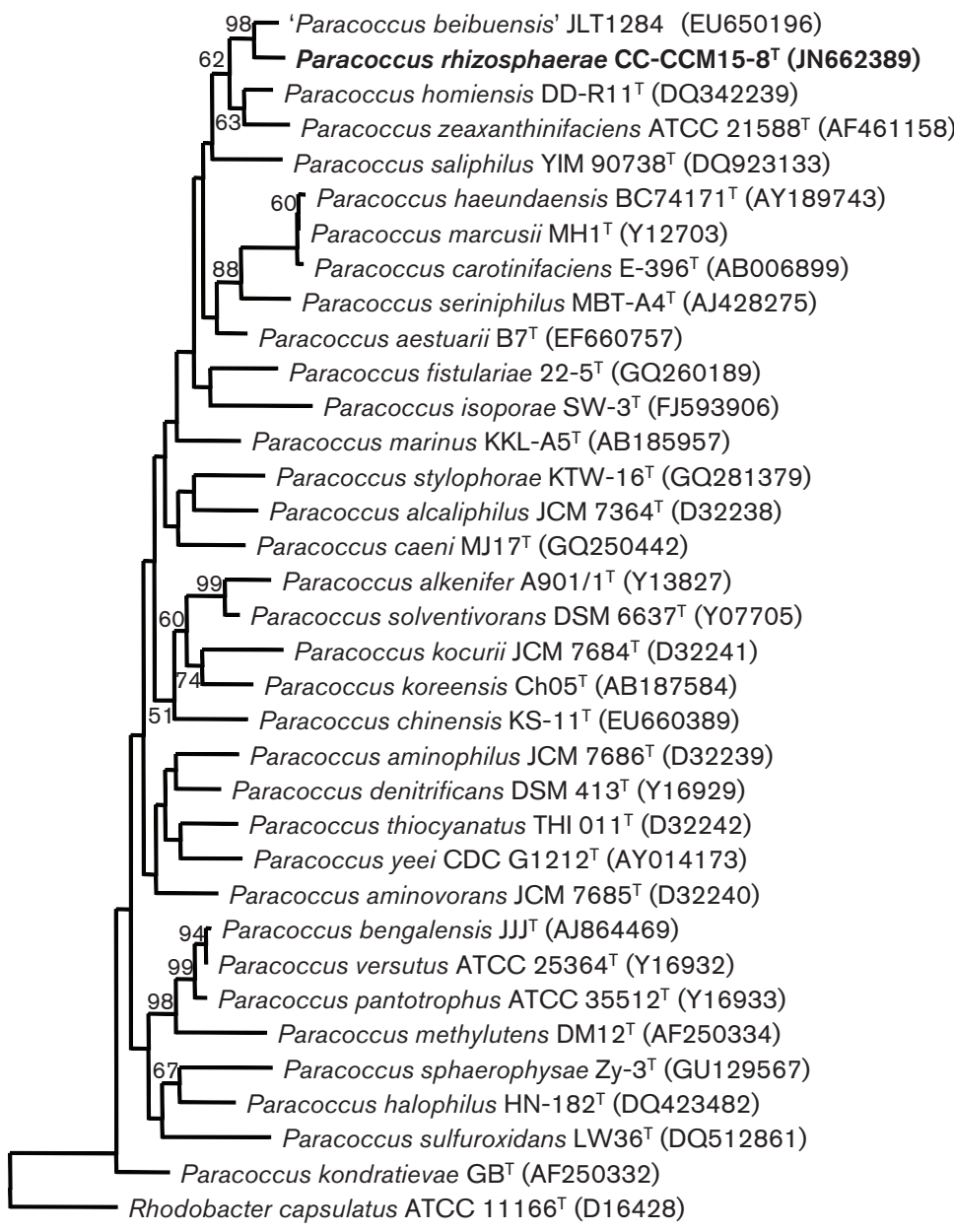

Fig. 1. Neighbour-joining phylogenetic tree based on 16S rRNA gene sequences of strain CC-CCM15-8 ${ }^{\top}$ and the type strains of recognized Paracoccus species. Numbers at nodes are bootstrap values (percentages of 1000 replications); only values $>50 \%$ are shown. Bar, 0.1 substitutions per nucleotide position.

than that of spermidine (Busse \& Auling, 1988; Hamana \& Matsuzaki, 1992). Also, the presence of sym-norspermidine has not been reported previously for Paracoccus species, but given the relatively low concentration, we do not attribute any taxonomic relevance to this finding. The diagnostic diamino acid of the peptidoglycan was extracted from PYE broth supplemented with $3.1 \%$ sea salt according to the method reported by Schleifer (1985). In agreement with all Proteobacteria, strain CC-CCM15- $8^{\mathrm{T}}$ contained meso-diaminopimelic acid as the diagnostic diamino acid. The results of comparative physiological characterization under identical test conditions (Kämpfer et al., 1991) for ' $P$. beibuensis' LMG $24872^{\mathrm{T}}$, P. aestuarii DSM $19484^{\mathrm{T}}$, P. zeaxanthinifaciens LMG $21993^{\mathrm{T}}$ and $P$. homiensis KACC $11518^{\mathrm{T}}$ are shown in Table 2.

DNA-DNA hybridizations between strain CC-CCM15-8 ${ }^{\mathrm{T}}$ and ' $P$. beibuensis' LMG $24872^{\mathrm{T}}$, $P$. aestuarii DSM $19484^{\mathrm{T}}$, $P$. zeaxanthinifaciens LMG $21993^{\mathrm{T}}$ and $P$. homiensis KACC $11518^{\mathrm{T}}$ were performed as described by Ziemke et al. (1998), indicating levels of relatedness of $24.9 \%(34.8 \%$ reciprocal analysis), $15.7 \%(17.5 \%), 17.7 \%(23.4 \%)$ and $16.0 \%(25.4 \%)$, respectively.

These data clearly show that strain CC-CCM15-8 $8^{\mathrm{T}}$ has features that are typical characteristics of the genus Paracoccus, such as a quinone system with ubiquinone Q-10 as the major component, a fatty acid profile mainly consisting of $\mathrm{C}_{18: 1} \omega 7 c$ and the major hydroxylated fatty acid $\mathrm{C}_{10: 0} 3-\mathrm{OH}$, and a complex polar lipid profile consisting of diphosphatidylglycerol, phosphatidylglycerol, phosphatidylcholine, and several uncharacterized lipids, phospholipids and glycolipids.

Strain CC-CCM15-8 $8^{\mathrm{T}}$ can be distinguished from its closest phylogenetic relatives in the genus Paracoccus based on several physiological and chemotaxonomic traits. The results of DNA-DNA hybridization experiments in addition to differences in $16 \mathrm{~S}$ rRNA gene sequences suggest that strain CC-CCM15-8 ${ }^{\mathrm{T}}$ represents a novel species of the genus Paracoccus, for which we propose the name Paracoccus rhizosphaerae sp. nov. 


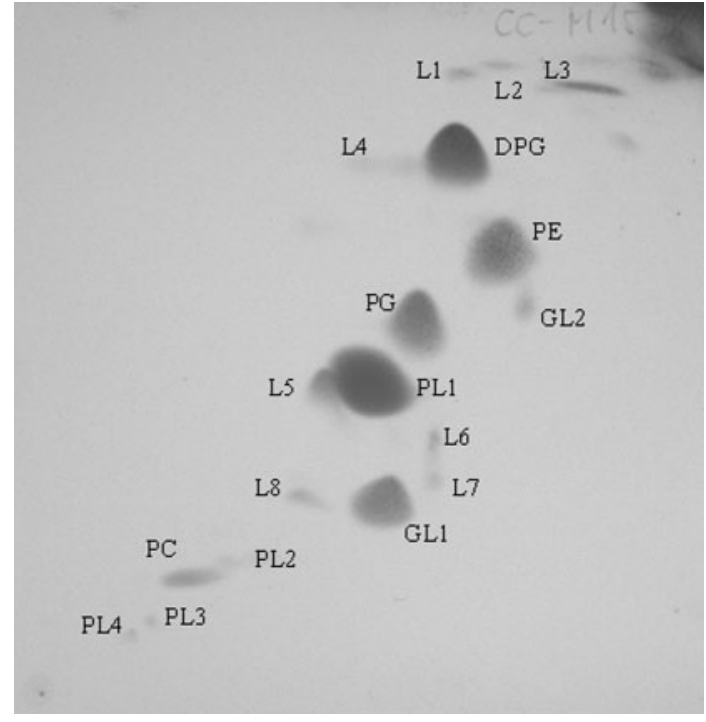

Fig. 2. Total polar lipid profile of strain $\mathrm{CC}-\mathrm{CCM} 15-8^{\top}$ after staining with molybdatophosphoric acid. DPG, Diphosphatidylglycerol; PE, phosphatidylethanolamine; PG, phosphatidylglycerol; PC, phosphatidylcholine; PL1-4, unidentified phospholipids; GL1, GL2, unidentified glycolipids; L1-8, unidentified lipids that did not react with the spray reagents specific for a free amino group, phosphate or sugars.

\section{Description of Paracoccus rhizosphaerae sp. nov.}

Paracoccus rhizosphaerae (rhi.zo.spha.e'ra.e. Gr. n. rhiza a root; L. n. sphaera a ball, sphere; N.L. n. rhizosphaera the rhizosphere; N.L. gen. n. rhizosphaerae of the rhizosphere).

Cells are coccoid-shaped, about $1.5-2.0 \mu \mathrm{m}$ in diameter. Gram-negative, oxidase-positive, catalase-positive and showing oxidative metabolism. Good growth occurs after $24 \mathrm{~h}$ on marine agar 2218 (Oxoid) at $28^{\circ} \mathrm{C}$; moderate growth occurs on tryptone soy agar, nutrient agar and R2A agar (all Oxoid). No growth occurs on MacConkey agar (Oxoid) at $28{ }^{\circ} \mathrm{C}$. Unable to grow at 4 or $40{ }^{\circ} \mathrm{C}$. Cells grow in the presence of $1.0-10.0 \% \mathrm{NaCl}$ (optimum, 6.0-7.0\%). Colonies on marine agar are yellow, circular, translucent and shiny with entire edges. The polyamine pattern consists of the major compounds spermidine and putrescine, moderate amounts of cadaverine and 1,3-diaminopropane, and minor amounts of spermine and sym-norspermidine. The peptidoglycan diamino acid is meso-diaminopimelic acid. The major quinone is ubiquinone Q-10. The polar lipid pattern comprises diphosphatidylglycerol, phosphatidylethanolamine, phosphatidylglycerol, phosphatidylcholine, four unknown phospholipids, two glycolipids and eight unidentified polar lipids that do not react with the spray reagents specific for a free amino group, phosphate or sugars. Major fatty acids are $\mathrm{C}_{18: 1} \omega 7 c$ and $\mathrm{C}_{10: 0} 3-\mathrm{OH}$. Physiological test results (including differential characteristics) are indicated in Table 1. Produces acid from D-glucose, sucrose and lactose (after 7 days of incubation), but not from adonitol,
Table 1. Phenotypic comparison of strain $\mathrm{CC}-\mathrm{CCM} 15-8^{\top}$ with the type strains of closely related species in the genus Paracoccus

Taxa: 1, strain CC-CCM15-8 ${ }^{\mathrm{T}}$; 2, 'P. beibuensis' LMG 24871; 3, P. aestuarii DSM $19484^{\mathrm{T}} ; 4$, P. homiensis DD-R11 ${ }^{\mathrm{T}}$; 5 , P. zeaxanthinifaciens (three strains); 6, P. carotinifaciens IFO $16121^{\mathrm{T}} ; 7, P$. haeundaensis KCCM $10460^{\mathrm{T}}$; 8, P. marcusii DSM $11574^{\mathrm{T}}$; 9, P. seriniphilus DSM $14827^{\mathrm{T}}$. Data for taxa 1-4 are from this study. Data for other reference strains are from Berry et al. (2003), Pukall et al. (2003), Lee et al. (2004) and Kim et al. (2006). w, Weakly positive; ND, not determined.

\begin{tabular}{|lccccccccc|}
\hline Characteristic & $\mathbf{1}$ & $\mathbf{2}$ & $\mathbf{3}$ & $\mathbf{4}$ & $\mathbf{5}$ & $\mathbf{6}$ & $\mathbf{7}$ & $\mathbf{8}$ & $\mathbf{9}$ \\
\hline Motility & + & - & - & + & - & + & - & - & - \\
Orange to red pigment & + & + & $+^{*}$ & - & + & + & + & + & - \\
Growth at $40{ }^{\circ} \mathrm{C}$ & - & - & $-{ }^{*}$ & + & + & - & - & - & - \\
Growth with $6 \% \mathrm{NaCl}$ & + & + & $-{ }^{*}$ & + & + & $\mathrm{w}$ & + & $\mathrm{W}$ & + \\
Nitrate reduction & - & - & - & - & - & - & + & - & + \\
Urease & - & - & - & - & + & - & - & - & - \\
Growth on: & & & & & & & & & \\
Acetic acid & + & + & + & $+\dagger$ & $-\dagger$ & $\mathrm{ND}$ & $\mathrm{ND}$ & - & + \\
Adonitol & + & + & $+{ }^{*}$ & $-\dagger$ & $-\dagger$ & + & - & + & + \\
L-Aspartate & + & + & + & $-\dagger$ & $+\dagger$ & + & $\mathrm{ND}$ & - & + \\
L-Asparagine & $\mathrm{ND}$ & $\mathrm{ND}$ & $\mathrm{ND}$ & + & + & + & - & - & + \\
i-Erythritol & $\mathrm{ND}$ & $\mathrm{ND}$ & $\mathrm{ND}$ & + & - & + & $\mathrm{ND}$ & + & + \\
Gentiobiose & $\mathrm{ND}$ & $\mathrm{ND}$ & $\mathrm{ND}$ & - & - & + & $\mathrm{ND}$ & + & - \\
L-Phenylalanine & - & - & - & $+\dagger$ & $-\dagger$ & $\mathrm{ND}$ & $\mathrm{ND}$ & - & - \\
Propionic acid & + & - & - & $+\dagger$ & $-\dagger$ & $\mathrm{ND}$ & $\mathrm{ND}$ & + & + \\
Quinic acid & $\mathrm{ND}$ & $\mathrm{ND}$ & $\mathrm{ND}$ & - & - & + & $\mathrm{ND}$ & + & - \\
L-Rhamnose & + & + & $-{ }^{*}$ & $+\dagger$ & $-\dagger$ & $\mathrm{ND}$ & - & - & - \\
D-Sorbitol & + & + & $-{ }^{*}$ & $+\dagger$ & $-\dagger$ & + & - & + & + \\
Succinic acid & $\mathrm{ND}$ & $\mathrm{ND}$ & $\mathrm{ND}$ & + & - & $\mathrm{ND}$ & $\mathrm{ND}$ & + & - \\
Xylitol & $\mathrm{ND}$ & $\mathrm{ND}$ & $\mathrm{ND}$ & - & - & + & $\mathrm{ND}$ & + & + \\
& & & & & & & & \\
\hline
\end{tabular}

${ }^{\star}$ Data congruent with those reported for P. aestuarii by Roh et al. (2009).

$\dagger$ Data congruent with those reported for $P$. homiensis and $P$. zeaxanthinifaciens by Kim et al. (2006).

L-arabinose, D-arabitol, dulcitol, erythritol, $i$-inositol, maltose, D-mannitol, melibiose, methyl $\alpha$-D-glucoside, raffinose, L-rhamnose, salicin, D-sorbitol, trehalose or D-xylose. Negative for urease activity, indole production, hydrolysis of casein, gelatin, starch, DNA and tyrosine, hydrogen sulphide production, and activity of arginine dihydrolase, lysine decarboxylase, ornithine decarboxylase and $\beta$-galactosidase (ONPG). Positive for hydrolysis of aesculin, $p$-nitrophenyl- $\alpha$-D-glucopyranoside, $p$-nitrophenyl- $\beta$-D-glucopyranoside, 2-deoxythymidine- 2 - $-p$-nitrophenyl-phosphate and L-alanine- $p$-nitroanilide. The following compounds are not hydrolysed: $p$-nitrophenyl- $\beta$-D-galactopyranoside, $p$-nitrophenyl- $\beta$-D-xylopyranoside, $p$-nitrophenyl- $\beta$-D-glucuronide, bis$p$-nitrophenyl-phosphate, bis- $p$-nitrophenyl-phenyl-phosphonate, bis- $p$-nitrophenyl-phosphoryl-choline, $\quad \gamma$-L-glutamate- $p$-nitroanilide and L-proline- $p$-nitroanilide. The following organic compounds are utilized as sole sources of carbon: L-arabinose, cellobiose, D-fructose, D-galactose, D-glucose, maltose, D-mannose, L-rhamnose, ribose, sucrose, trehalose, 
Table 2. Fatty acid composition of strain $\mathrm{CC}-\mathrm{CCM} 15-8^{\top}$ and the type strains of closely related species in the genus Paracoccus

Taxa: 1, strain CC-CC-M15-8 ${ }^{\mathrm{T}}$; 2, 'P. beibuensis' LMG 24871 ${ }^{\mathrm{T}} ; 3$, P. aestuarii DSM 19484 ${ }^{\mathrm{T}} ; 4$, P. homiensis DD-R11 ${ }^{\mathrm{T}}$; 5, P. zeaxanthinifaciens (mean value from three strains); 6, P. carotinifaciens IFO $16121^{\mathrm{T}}$; 7, P. haeundaensis KCCM $10460^{\mathrm{T}}$; 8, P. marcusii DSM 11574 $4^{\mathrm{T}}$; 9 , P. seriniphilus DSM $14827^{\mathrm{T}}$. Data for taxa 1-5 are from this study. Data in parentheses in columns 3-5 are from the literature (see footnotes). Data for the other strains are from Berry et al. (2003), Pukall et al. (2003), Lee et al. (2004) and Kim et al. (2006). Values are percentages of total fatty acids; -, not detected or $<1 \%$.

\begin{tabular}{|c|c|c|c|c|c|c|c|c|c|}
\hline Fatty acid & 1 & 2 & $3^{\star}$ & $4 \dagger$ & $5 \dagger$ & 6 & 7 & 8 & 9 \\
\hline $\mathrm{C}_{10: 0} 3-\mathrm{OH}$ & 5.2 & 4.4 & $2.8(2.5)$ & $3.2(2.6)$ & $5.5(4.9)$ & 3.4 & 2.1 & 6.2 & 7.9 \\
\hline \multicolumn{10}{|l|}{ Unidentified } \\
\hline ECL 11.799 & 4.6 & 3.8 & $2.9(-)$ & $2.8(2.4)$ & $5.8(3.6)$ & 2.8 & - & 4.9 & - \\
\hline ECL 14959 & 2.2 & - & - & 0.8 & $-(-)$ & - & - & - & - \\
\hline ECL 15275 & - & - & - & $-(-)$ & $-(1.6)$ & 1.1 & - & 2.9 & - \\
\hline $\mathrm{C}_{12: 1} \omega 7 c$ & - & - & - & $-(-)$ & $-(-)$ & - & 2.0 & - & - \\
\hline $\mathrm{C}_{12: 0} \mathrm{ALDE}$ & 1.0 & 0.6 & $0.7(-)$ & $1.4(1.8)$ & $1.3(-)$ & - & - & - & - \\
\hline $\mathrm{C}_{14: 0} 3-\mathrm{OH}$ & - & - & - & $-(-)$ & $-(-)$ & - & 1.5 & - & - \\
\hline $\mathrm{C}_{18: 1} \omega 7 c$ & 73.8 & 77.7 & $81.7(68.9)$ & $75.1(78.9)$ & $74.6(80.2)$ & 84.0 & 84.3 & 80.3 & 83.5 \\
\hline $\mathrm{C}_{17: 1} \omega 8 c$ & - & 1.8 & - & - & - & - & - & - & - \\
\hline $\mathrm{C}_{18: 0}$ & 6.4 & 8.1 & $7.9(18.1)$ & $5.6(4.5)$ & $4.9(3.6)$ & 5.2 & 7.8 & 2.6 & 2.5 \\
\hline $\mathrm{C}_{18: 0} 3-\mathrm{OH}$ & 2.5 & - & - & $0.9(1.1)$ & $-(-)$ & - & - & - & - \\
\hline 11-Methyl $\mathrm{C}_{18: 1} \omega 7 c$ & - & - & - & $3.6(5.8)$ & $-(-)$ & - & - & - & 1.5 \\
\hline Summed feature $2 \ddagger$ & 3.6 & 3.2 & $2.6(2.4)$ & $-(-)$ & $3.5(2.9)$ & 2.1 & - & 3.0 & - \\
\hline
\end{tabular}

${ }^{*}$ Data in parentheses from Roh et al. (2009).

$\dagger$ Data in parentheses from Kim et al. (2006).

$¥$ Summed feature 2 comprises $\mathrm{C}_{14: 0} 3$ - $\mathrm{OH}$ and/or $\mathrm{C}_{16: 1}$ iso I.

adonitol, D-mannitol, D-sorbitol, acetate, propionate, cisaconitate, 4-aminobutyrate, citrate, fumarate, glutarate, DLlactate, L-malate, 2-oxoglutarate, pyruvate, L-alanine, L-aspartate, L-leucine, L-proline and L-serine. The following compounds are not utilized as sole source of carbon in mineral-salt medium (Kämpfer et al., 1991): $N$-acetyl-Dglucosamine, maltose, $N$-acetylgalactosamine, L-arbutin, gluconate, glycerol, maltitol, $\alpha$-melibiose, salicin, D-xylose, $i$-inositol, putrescine, trans-aconitate, adipate, DL-3-hydroxybutyrate, azelate, itaconate, suberate, mesaconate, $\beta$-alanine, L-ornithine, L-phenylalanine, L-histidine, L-tryptophan, 3-hydroxybenzoate, 4-hydroxybenzoate and phenylacetate.

The type strain, CC-CCM15- $8^{\mathrm{T}}$ (=LMG $26205^{\mathrm{T}}=\mathrm{CCM}$ $7904^{\mathrm{T}}$ ), was isolated from a rhizosphere soil sample of the plant Crossostephium chinense (L.) Makino (Seremban) from Budai Township, Chiayi County, Taiwan.

\section{Acknowledgements}

We are grateful to Gundula Will and Carmen Schult for excellent technical assistance. We thank Dr S.-W. Kwon for providing the type strain of $P$. homiensis prior to publication of the species description.

\section{References}

Beijerinck, M. W. \& Minkman, D. C. J. (1910). Bildung und verbrauch von stickstoffoxyd durch bakterien. Zentralbl. Bakt. Hyg. 25, 30-63.

Berry, A., Janssens, D., Hümbelin, M., Jore, J. P. M., Hoste, B., Cleenwerck, I., Vancanneyt, M., Bretzel, W., Mayer, A. F. \& other authors (2003). Paracoccus zeaxanthinifaciens sp. nov., a zeaxanthinproducing bacterium. Int J Syst Evol Microbiol 53, 231-238.

Busse, H. J. \& Auling, G. (1988). Polyamine pattern as a chemotaxonomic marker within the Proteobacteria. Syst Appl Microbiol 11, 1-8.

Chen, M. H., Sheu, S. Y., Chen, C. A., Wang, J. T. \& Chen, W. M. (2011). Paracoccus isoporae sp. nov., isolated from the reefbuilding coral Isopora palifera. Int J Syst Evol Microbiol 61, 11381143.

Collins, M. D. \& Jones, D. (1980). Lipids in the classification and identification of coryneform bacteria containing peptidoglycans based on 2,4-diaminobutyric acid. J Appl Bacteriol 48, 459-470.

Collins, M. D., Pirouz, T., Goodfellow, M. \& Minnikin, D. E. (1977). Distribution of menaquinones in actinomycetes and corynebacteria. J Gen Microbiol 100, 221-230.

Daneshvar, M. I., Hollis, D. G., Weyant, R. S., Steigerwalt, A. G., Whitney, A. M., Douglas, M. P., Macgregor, J. P., Jordan, J. G., Mayer, L. W. \& other authors (2003). Paracoccus yeeii sp. nov. (formerly CDC group EO-2), a novel bacterial species associated with human infection. J Clin Microbiol 41, 1289-1294.

Davis, D. H., Doudoroff, M., Stanier, R. Y. \& Mandel, M. (1969). Proposal to reject the genus Hydrogenomonas: taxonomic implications. Int J Syst Bacteriol 19, 375-390.

Deng, Z. S., Zhao, L. F., Xu, L., Kong, Z. Y., Zhao, P., Qin, W., Chang, J. L. \& Wei, G. H. (2011). Paracoccus sphaerophysae sp. nov., a siderophore-producing, endophytic bacterium isolated from root nodules of Sphaerophysa salsula. Int J Syst Evol Microbiol 61, 665-669.

Doronina, N. V. \& Trotsenko, Y. A. (2000). A novel plant-associated thermotolerant alkaliphilic methylotroph of the genus Paracoccus. Microbiology 69, 593-598 (in Russian).

Doronina, N. V., Trotsenko, Y. A., Krausova, V. I. \& Suzina, N. E. (1998). Paracoccus methylutens sp. nov. - a new aerobic facultatively 
methylotrophic bacterium utilizing dichloromethane. Syst Appl Microbiol 21, 230-236.

Doronina, N. V., Trotsenko, Y. A., Kuznetzov, B. B. \& Tourova, T. P. (2002). Emended description of Paracoccus kondratievae. Int J Syst Evol Microbiol 52, 679-682.

Ghosh, W., Mandal, S. \& Roy, P. (2006). Paracoccus bengalensis sp. nov., a novel sulfur-oxidizing chemolithoautotroph from the rhizospheric soil of an Indian tropical leguminous plant. Syst Appl Microbiol 29, 396-403.

Groth, I., Schumann, P., Weiss, N., Martin, K. \& Rainey, F. A. (1996). Agrococcus jenensis gen. nov., sp. nov., a new genus of actinomycetes with diaminobutyric acid in the cell wall. Int J Syst Bacteriol 46, 234239.

Hamana, K. \& Matsuzaki, S. (1992). Taxonomic significance of polyamine synthesis in Paracoccus. J Gen Appl Microbiol 38, 93-103.

Harker, M., Hirschberg, J. \& Oren, A. (1998). Paracoccus marcusii sp. nov., an orange gram-negative coccus. Int J Syst Bacteriol 48, 543-548.

Harrison, A. P. (1983). Genomic and physiological comparisons between heterotrophic thiobacilli and Acidiphilium cryptum, Thiobacillus versutus sp. nov., and Thiobacillus acidophilus nom. rev. Int J Syst Bacteriol 33, 211-217.

Kämpfer, P. \& Kroppenstedt, R. M. (1996). Numerical analysis of fatty acid patterns of coryneform bacteria and related taxa. Can $J$ Microbiol 42, 989-1005.

Kämpfer, P. \& Kroppenstedt, R. M. (2004). Pseudonocardia benzenivorans sp. nov. Int J Syst Evol Microbiol 54, 749-751.

Kämpfer, P., Steiof, M. \& Dott, W. (1991). Microbiological characterisation of a fuel-oil contaminated site including numerical identification of heterotrophic water and soil bacteria. Microb Ecol 21, 227-251.

Kämpfer, P., Dreyer, U., Neef, A., Dott, W. \& Busse, H.-J. (2003). Chryseobacterium defluvii sp. nov., isolated from wastewater. Int J Syst Evol Microbiol 53, 93-97.

Katayama, Y., Hiraishi, A. \& Kuraishi, H. (1995). Paracoccus thiocyanatus sp. nov., a new species of thiocyanate-utilizing facultative chemolithotroph, and transfer of Thiobacillus versutus to the genus Paracoccus as Paracoccus versutus comb. nov. with emendation of the genus. Microbiology 141, 1469-1477.

Khan, S. T., Takaichi, S. \& Harayama, S. (2008). Paracoccus marinus sp. nov., an adonixanthin diglucoside-producing bacterium isolated from coastal seawater in Tokyo Bay. Int J Syst Evol Microbiol 58, 383386.

Kim, B. Y., Weon, H. Y., Yoo, S. H., Kwon, S. W., Cho, Y. H., Stackebrandt, E. \& Go, S. J. (2006). Paracoccus homiensis sp. nov., isolated from a sea-sand sample. Int J Syst Evol Microbiol 56, 23872390.

Kim, Y. O., Kong, H. J., Park, S., Kang, S. J., Kim, K. K., Moon, D. Y., Oh, T. K. \& Yoon, J. H. (2010). Paracoccus fistulariae sp. nov., a lipolytic bacterium isolated from bluespotted cornetfish, Fistularia commersonii. Int J Syst Evol Microbiol 60, 2908-2912.

La, H. J., Im, W. T., Ten, L. N., Kang, M. S., Shin, D. Y. \& Lee, S. T. (2005). Paracoccus koreensis sp. nov., isolated from anaerobic granules in an upflow anaerobic sludge blanket (UASB) reactor. Int J Syst Evol Microbiol 55, 1657-1660.

Lee, J. H., Kim, Y. S., Choi, T. J., Lee, W. J. \& Kim, Y. T. (2004). Paracoccus haeundaensis sp. nov., a Gram-negative, halophilic, astaxanthin-producing bacterium. Int $J$ Syst Evol Microbiol 54, 1699-1702.

Li, H. F., Qu, J. H., Yang, J. S., Li, Z. J. \& Yuan, H. L. (2009). Paracoccus chinensis sp. nov., isolated from sediment of a reservoir. Int J Syst Evol Microbiol 59, 2670-2674.
Lipski, A., Reichert, K., Reuter, B., Spröer, C. \& Altendorf, K. (1998). Identification of bacterial isolates from biofilters as Paracoccus alkenifer sp. nov. and Paracoccus solventivorans with emended description of Paracoccus solventivorans. Int J Syst Bacteriol 48, 529536.

Liu, X. Y., Wang, B. J., Jiang, C. Y. \& Liu, S. J. (2006). Paracoccus sulfuroxidans sp. nov., a sulfur oxidizer from activated sludge. Int $J$ Syst Evol Microbiol 56, 2693-2695.

Liu, Z. P., Wang, B. J., Liu, X. Y., Dai, X., Liu, Y. H. \& Liu, S. J. (2008). Paracoccus halophilus sp. nov., isolated from marine sediment of the South China Sea, China, and emended description of genus Paracoccus Davis 1969. Int J Syst Evol Microbiol 58, 257-261.

Ludwig, W., Mittenhuber, G. \& Friedrich, C. G. (1993). Transfer of Thiosphaera pantotropha to Paracoccus denitrificans. Int J Syst Bacteriol 43, 363-367.

Minnikin, D. E., Collins, M. D. \& Goodfellow, M. (1979). Fatty acid and polar lipid composition in the classification of Cellulomonas, Oerskovia and related taxa. J Appl Bacteriol 47, 87-95.

Nokhal, T. H. \& Schlegel, H. G. (1983). Taxonomic study of Paracoccus denitrificans. Int J Syst Bacteriol 33, 26-37.

Ohara, M., Katayama, Y., Tsuzaki, M., Nakamoto, S. \& Kuraishi, H. (1990). Paracoccus kocurii sp. nov., a tetramethylammoniumassimilating bacterium. Int J Syst Bacteriol 40, 292-296.

Pukall, R., Laroche, M., Kroppenstedt, R. M., Schumann, P., Stackebrandt, E. \& Ulber, R. (2003). Paracoccus seriniphilus sp. nov., an L-serine-dehydratase-producing coccus isolated from the marine bryozoan Bugula plumosa. Int J Syst Evol Microbiol 53, 443-447.

Rainey, F. A., Kelly, D. P., Stackebrandt, E., Burghardt, J., Hiraishi, A., Katayama, Y. \& Wood, A. P. (1999). A re-evaluation of the taxonomy of Paracoccus denitrificans and a proposal for the combination Paracoccus pantotrophus comb. nov. Int J Syst Bacteriol 49, 645-651.

Robertson, I. A. \& Kuenen, J. G. (1983). Thiosphaera pantotropha gen. nov., sp. nov., a facultatively anaerobic, facultatively autotrophic sulphur bacterium. J Gen Microbiol 129, 2847-2855.

Robinson, J. \& Gibbons, N. E. (1952). The effect of salts on the growth of Micrococcus halodentrificans n. sp. Can J Bot 30, 147-154.

Roh, S. W., Nam, Y. D., Chang, H. W., Kim, K. H., Kim, M. S., Shin, Robertson K. S., Yoon, J. H., Oh, H. M. \& Bae, J. W. (2009). Paracoccus aestuarii sp. nov., isolated from tidal flat sediment. Int J Syst Evol Microbiol 59, 790-794.

Schleifer, K. P. (1985). Analysis of the chemical composition and primary structure of murein. Methods Microbiol 18, 123-156.

Siller, H., Rainey, F. A., Stackebrandt, E. \& Winter, J. (1996). Isolation and characterization of a new gram-negative, acetone-degrading, nitrate-reducing bacterium from soil, Paracoccus solventivorans sp. nov. Int J Syst Bacteriol 46, 1125-1130.

Skerman, V. B. D., McGowan, V. \& Sneath, P. H. A. (1980). Approved lists of bacterial names. Int J Syst Bacteriol 30, 225-420.

Stolz, A., Busse, H.-J. \& Kämpfer, P. (2007). Pseudomonas knackmussii sp. nov. Int J Syst Evol Microbiol 57, 572-576.

Tamura, K., Dudley, J., Nei, M. \& Kumar, S. (2007). MEGA4: molecular evolutionary genetics analysis (MEGA) software version 4.0. Mol Biol Evol 24, 1596-1599.

Tsubokura, A., Yoneda, H. \& Mizuta, H. (1999). Paracoccus carotinifaciens sp. nov., a new aerobic gram-negative astaxanthinproducing bacterium. Int J Syst Bacteriol 49, 277-282.

Urakami, T., Tamaoka, J., Suzuki, K. I. \& Komagata, K. (1989). Paracoccus alcaliphilus sp. nov., an alkaliphilic and facultatively methylotrophic bacterium. Int J Syst Bacteriol 39, 116-121.

Urakami, T., Araki, H., Oyanagi, H., Suzuki, K. I. \& Komagata, K. (1990). Paracoccus aminophilus sp. nov. and Paracoccus aminovorans 
sp. nov., which utilize $N, N$-dimethylformamide. Int J Syst Bacteriol 40, 287-291.

Wang, Y., Tang, S. K., Lou, K., Mao, P. H., Jin, X., Jiang, C. L., Xu, L. H. \& Li, W. J. (2009). Paracoccus saliphilus sp. nov., a halophilic bacterium isolated from a saline soil. Int J Syst Evol Microbiol 59, 1924-1928.
Zheng, O., Wang, Y., Chen, C., Wang, Y., Xia, X., Fu, Y., Zhang, R. \& Jiao, N. (2011). Paracoccus beibuensis sp. nov., isolated from the South China Sea. Curr Microbiol 62, 710-714.

Ziemke, F., Höfle, M. G., Lalucat, J. \& Rosselló-Mora, R. (1998). Reclassification of Shewanella putrefaciens Owen's genomic group II as Shewanella baltica sp. nov. Int J Syst Bacteriol 48, 179-186. 